\title{
RANCANGAN ALAT PEMBUATAN BIOETANOL DARI BAHAN BAKU KULIT DURIAN
}

\author{
Irvan, Bambang Trisakti, Luri Adriani, Reviana Revitasari \\ Departemen Teknik Kimia, Fakultas Teknik, Universitas Sumatera Utara \\ Jl. Almamater Kampus USU Medan, 20155 Indonesia \\ Email: i_v_a_n_mz@yahoo.com
}

\begin{abstract}
Abstrak
Pada penelitian ini, sebuah unit peralatan untuk pembuatan bioetanol berbahan baku kulit durian dirancang dengan kapasitas proses 100 liter per siklus secara batch. Peralatan utama yang dirancang antara lain fermentor dan unit distilasi. Tangki fermentor dirancang dengan diamater $43 \mathrm{~cm}$ dan tinggi $86 \mathrm{~cm}$, dilengkapi dengan 2 buah pengaduk manual tipe paddle dan mempunyai diameter $30 \mathrm{~cm}$. Peralatan utama lainnya, tangki distilasi dibuat dari bahan stainless steel dengan diameter $48 \mathrm{~cm}$ dan tinggi $54 \mathrm{~cm}$, dilengkapi dengan heater untuk memanaskan larutan hasil proses fermentasi dan tangki air pendingin untuk mengkondensasikan bioetanol dari bentuk uap. Waktu yang dibutuhkan untuk satu siklus fermentasi dengan proses batch adalah 7 hari 7 jam. Waktu yang dibutuhkan untuk satu siklus proses pembuatan bioetanol dengan proses batch adalah 8 hari 4 jam. Pada penelitian ini, diuji kelayakan unit pembuatan bioetanol yang terdiri dari tangki fermentor dan tangki distilasi dengan kondisi proses fermentasi 7 hari dan konsentrasi ragi $6 \%$, dan distilasi pada suhu $80^{\circ} \mathrm{C}$. Hasil yang diperoleh kadar bioetanol hasil fermentasi sebesar 8,98\% dan kadar bioetanol hasil distilasi sebesar 74,96\%.
\end{abstract}

Kata kunci : kulit durian, bioetanol, fermentor, unit distilasi, rancangan alat

\begin{abstract}
In this research, the bioethanol production unit using durian peel as raw material was designed with capacity process of 100 liters per cycle in batch process. The main equipments were designed fermenter and distillation unit. Fermenter tank was designed with $43 \mathrm{~cm}$ of diameter and $86 \mathrm{~cm}$ of height which was equipped with two manual paddle impeller of $30 \mathrm{~cm}$ in diameter. The other of main equipments, distillation tank was made of stainless steel with $48 \mathrm{~cm}$ of diameter and $54 \mathrm{~cm}$ of height, which was equipped with heater to heat the liquid of fermentation process and cooling tank to cool vaporised bioethanol. The time required for one cycle of fermentation with batch process was 7 days and 7 hours. While the time required for one cycle of bioethanol production with batch process was 8 days and 4 hours. The feasibility of bioethanol production unit in which consists of fermenter tank and distillation tank under condition process of 7 days and yeast concentration of $6 \%$ and distillation temperature of $80^{\circ} \mathrm{C}$ was tested. The results obtained were 8,98\% of bioethanol concentration during fermentation and 74,96\% of bioethanol concentration during distillation.
\end{abstract}

Keywords : durian peel, bioethanol, fermenter, distillation unit, equipment design

\section{Pendahuluan}

Bioetanol merupakan senyawa alkohol yang diperoleh melalui proses fermentasi biomassa (bahan bergula, bahan berpati dan bahan berlignoselulosa) dengan bantuan mikroorganisme $[4,9]$. Perkembangan bioetanol di Indonesia saat ini cukup menjadi perhatian. Banyak dilakukan penelitian tentang pembuatan bioetanol dari berbagai bahan baku biomassa baik dalam skala laboratorium dan bahkan sudah banyak pabrik bioetanol yang beroperasi di Indonesia. Sebagai senyawa alkohol, kegunaan bioetanol sangat luas terutama sebagai sumber energi terbarukan, sehingga bioetanol menjadi salah satu energi yang dipertimbangkan dalam Peraturan Pemerintah No. 5 Tahun 2006 tentang kebijakan energi nasional [12]. Oleh karena itu, hasil penelitian skala laboratorium perlu dikembangkan menjadi skala yang lebih besar dengan membangun sebuah unit pembuatan bioetanol. Adapun yang menjadi pertimbangan dalam mendesain unit pembuatan bioetanol adalah pemilihan bahan baku, pemilihan teknologi proses dan ukuran plant yang akan dibangun [19]. Tulisan ini memaparkan hasil perancangan, pabrikasi dan pengujian unjuk kerja dari unit pembuatan bioetanol dengan bahan baku kulit durian (terdiri dari fermentor dan distilator), serta waktu satu siklus proses batch pembuatan bioetanol dengan bahan baku kulit durian.

\section{Teori}

Kulit durian merupakan komposisi terbesar yang terdapat pada buah durian yaitu $60-75 \%$ dari berat buah [6]. Secara proporsional, kulit durian mengandung unsur selulosa yang tinggi (50-60\%) [11], sehingga kulit durian dapat dimanfaatkan sebagai bahan baku pembuatan bioetanol. Inti dari proses pembuatan bioetanol adalah proses fermentasi mengubah gula menjadi etanol dengan bantuan mikroorganisme. Mikroorganisme yang biasa digunakan dalam fermentasi etanol adalah Saccharomyces cerevisiae. Semua bahan biomassa harus diubah menjadi gula terlebih dahulu sebelum melewati proses fermentasi $[13,15]$.

Secara umum, proses pembuatan bioetanol terdiri dari tiga tahapan yaitu persiapan bahan baku (mengubah bahan baku biomassa menjadi gula), fermentasi dan pemurnian. Proses persiapan bahan 
baku (pre-treatment) dipilih berdasarkan bahan baku yang digunakan [13]. Kulit durian merupakan bahan baku bioetanol dari sumber berlignoselulosa, sehingga dibutuhkan perlakuan awal mengubah selulosa kulit durian menjadi gula sebelum proses fermentasi. Pada tahap ini dipilih proses hidrotermal liquid hot water $(L H W)$ yaitu menggunakan cairan air panas untuk mengubah bahan baku selulosa menjadi gula dengan tekanan tinggi. Air dibawah tekanan tinggi dapat menembus ke dalam biomassa selulosa hidrat dan menghilangkan lignin. Keuntungan dari proses ini tidak membutuhkan bahan kimia dalam proses dan netralisasi hidrolisat. Selain itu, tangki hidrolisis pada proses ini tidak membutuhkan bahan tahan korosi [16].

Tahap selanjutnya adalah proses fermentasi. Fermentasi merupakan proses biokimia dimana mikroorganisme yang berperan dalam fermentasi akan menghasilkan enzim yang mampu mengkonversi substrat menjadi etanol [15]. Fermentasi bioetanol termasuk dalam proses fermentasi anaerob. Konversi gula sederhana menjadi etanol dalam proses fermentasi mencapai 8-12\% kandungan etanol dan setelah itu mikroorganisme menjadi tidak aktif lagi. Selain etanol, dihasilkan gas $\mathrm{CO}_{2}$ dalam proses fermentasi tersebut [13]. Beberapa faktor yang dapat mempengaruhi fermentasi bioetanol adalah suhu, $\mathrm{pH}$, oksigen, unsur hara, media fermentasi dan pengadukan [2,10]. Pada penelitian Torija (2002), suhu tidak hanya mempengaruhi kinetika fermentasi, tetapi juga pertumbuhan mikrorganisme. Pertumbuhan yang baik pada suhu $25-30^{\circ} \mathrm{C}$ [17]. Suhu yang terlalu tinggi menyebabkan pembentukan asam asetat yang bersifat racun, sedangkan suhu yang terlalu rendah menyebabkan proses fermentasi menjadi lambat dan tidak ekonomis. $\mathrm{pH}$ yang dibutuhkan untuk fermentasi bioetanol dijaga 4,5-5,0. Fermentasi bioetanol merupakan fermentasi anaerob sehingga tidak membutuhkan oksigen selama proses berlangsung [2]. Dalam proses fermentasi pengadukan berfungsi untuk meratakan kontak sel dan substrat, menjaga agar mikroorganisme tidak mengendap di bawah dan menratakan temperatur di seluruh wadah fermentasi [10]. Proses fermentasi berlangsung di dalam fermentor.

Tahap terakhir dari proses ini adalah pemurnian. Etanol hasil fermentasi memiliki kandungan etanol yang rendah, sehingga harus dimurnikan dengan cara pemisahan air dan etanol dengan cara distilasi. Etanol hasil distilasi dapat mencapai kadar 95\%, tetapi tidak dapat melebihi kadar tersebut karena campuran etanol dan air bersifat azeotrop. Sehingga diperlukan pemurnian lebih lanjut untuk menghasilkan fuel grade ethanol (FGE) dengan kadar 99\% [2,13].
Peralatan yang digunakan dalam proses pembuatan bioetanol tergantung pada proses yang dipilih. Bioetanol dari kulit durian menggunakan proses $L H W$ dalam perlakuan awal sehingga dibutuhkan tangki bertekanan untuk proses tersebut. Fermentasi berlangsung di dalam fermentor, biasanya untuk operasi yang melibatkan mikroorganisme dipilih fermentor tangki berpengaduk karena proses pencampuran lebih baik dan biaya operasi rendah [1]. Dan selanjutnya proses distilasi berlangsung di dalam tangki distilator.

Pengembangan sebuah penelitian skala laboratorium menjadi skala pilot merupakan peralihan dari studi laboratorium sebelum diterapkan pada skala industri. Skala pilot plant bukan merupakan scale-up dari peralatan laboratorium, tetapi sebagai simulasi kecil dari operasi industri di masa depan [8]. Oleh karena itu, skala pilot dibutuhkan untuk menguji teknologi yang akan digunakan pada skala industri [3]. Selain itu, skala pilot plant bertujuan untuk mengoptimalkan parameter operasi proses, pengujian sistem kontrol proses dan prosedur, pengujian bahan konstruksi, mengoptimalkan desain peralatan, mempersiapkan estimasi biaya operasi dan evaluasi ekonomi proyek [8].

\section{Metodologi Penelitian}

\section{Lokasi dan Bahan Penelitian}

Penelitian dilakukan di Laboratorium Proses Industri Kimia Universitas Sumatera Utara. Bahan yang digunakan dalam pabrikasi peralatan pembuatan bioetanol dari bahan baku kulit durian yang terdiri dari tangki fermentor dan tangki distilasi antara lain drum plastik, stainless steel, alumunium, dan lain-lain. Sedangkan bahan yang digunakan adalah kulit durian, ragi dan air.

\section{Peralatan}

Fermentor dan tangki distilasi dirancang dan dibangun dengan kapasitas proses 100 liter per siklus secara batch. Fermentor merupakan wadah tempat terjadinya proses fermentasi perubahan gula menjadi etanol. Pada penelitian ini dibangun fermentor dengan tipe tangki berpengaduk dan dilengkapi dengan pengaduk paddle. Distilator berfungsi sebagai tangki untuk memurnikan bioetanol hasil fermentasi. Tangki distilasi dilengkapi dengan heater sebagai pemanas dan tangki air pendingin sebagai wadah penyimpanan air untuk mendinginkan uap panas hasil distilasi. Selain peralatan utama tersebut, terdapat beberapa alat ukur, indikator dan panel antara lain termokopel dan termometer, kontrol panel dan level indikator. Pada fermentor dipasang termometer, sedangkan pada tangki distilator dipasang 
termometer, termokopel, level indikator, dan kontrol panel sebagai alat ukur dan indikator.

\section{Prosedur dan Analisis}

Tahapan-tahapan penelitian ini adalah penentuan ukuran plant, perancangan dan pabrikasi peralatan, kalibrasi terhadap peralatan dan aksesoris, operasional dan pengujian kelayakan unit pembuatan bioetanol berdasarkan kadar bioetanol yang dihasilkan.

Prosedur operasional unit pembuatan bioetanol dengan bahan baku kulit durian disesuaikan dengan prosedur penelitian pembuatan bioetanol dalam skala laboratorium, terdiri dari proses hidrolisis dengan metode LHW, fermentasi dan distilasi. Proses fermentasi berlangsung pada temperatur kamar selama 7 hari dengan penambahan ragi $6 \%$ dari berat bahan baku. Dan proses distilasi dengan kondisi proses pada suhu distilasi $80^{\circ} \mathrm{C}$ selama 3 jam.

Kalibrasi/uji peralatan dan aksesoris terdiri dari uji kebocoran dan kalibrasi suhu tangki distilasi. Sedangkan hasil fermentasi dan distilasi diukur kadar etanolnya dengan menggunakan gas chromatography (GC).

\section{Hasil dan Pembahasan}

\section{Perancangan Peralatan Utama Fermentor}

Fermentor merupakan sebuah wadah tempat berlangsungnya proses fermentasi. Telah dirancang dan dibangun fermentor dengan kondisi proses anaerob dan suhu fermentasi pada suhu kamar. Perancangan fermentor sesuai dengan standar spesifikasi sebagai berikut [18]:

$\mathrm{H} / \mathrm{D}_{\mathrm{t}}=2$

Volume kerja maksimum $=75-80 \%$,

$$
\text { minimum }=20 \%
$$

$$
\mathrm{V}=\pi / 4 \cdot \mathrm{D}_{\mathrm{t}}^{2} \cdot \mathrm{H}
$$

Keterangan:

$$
\begin{array}{lll}
\mathrm{V} & =\text { Volume fermentor } & \left(\mathrm{cm}^{3}\right) \\
\mathrm{H} & =\text { Tinggi fermentor } & (\mathrm{cm}) \\
\mathrm{D}_{\mathrm{t}} & =\text { Diameter fermentor } & (\mathrm{cm})
\end{array}
$$

Fermentor dilengkapi dengan pengaduk paddle dan perancangan pengaduk dirancang sesuai dengan spesifikasi sebagai berikut [5]:

$\mathrm{D}_{\mathrm{a}}: \mathrm{D}_{\mathrm{t}}=0,6-0,8$

$\mathrm{W}: \mathrm{D}_{\mathrm{a}}=1 / 6-1 / 10$

$\mathrm{C}: \mathrm{D}_{\mathrm{a}}=1: 3$

Keterangan:
$\mathrm{D}_{\mathrm{t}} \quad=$ Diameter tangki
$\mathrm{D}_{\mathrm{a}}=$ Diamater impeler
$\mathrm{W}=$ Lebar impeler
(cm)
$\mathrm{C} \quad=$ Tinggi pengaduk dari dasar $\quad(\mathrm{cm})$

Desain teknikal dari fermentor dan pengaduk ditampilkan pada gambar 1, sedangkan spesifikasi dari tangki fermentor dan pengaduk ditampilkan pada tabel 1 .

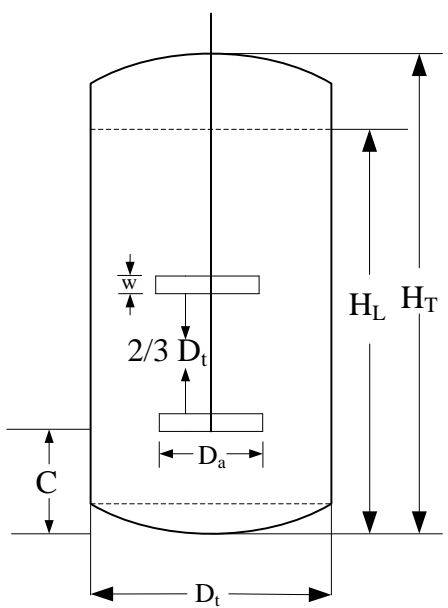

Gambar 1. Desain Teknikal Tangki Fermentor dan Pengaduk Paddle

Tabel 1. Spesifikasi Tangki Fermentor dan Pengaduk Paddle

\begin{tabular}{|l|c|}
\hline \multicolumn{1}{|c|}{ Dimensi } & Besaran \\
\hline Tangki & \\
- Tinggi tangki & $86 \mathrm{~cm}$ \\
- Diameter tangki & $43 \mathrm{~cm}$ \\
Pengaduk & \\
- Jumlah bilah & 2 \\
- Panjang bilah & $30 \mathrm{~cm}$ \\
- Tinggi dari dasar & $10 \mathrm{~cm}$ \\
- Jarak antar bilah & $24 \mathrm{~cm}$ \\
- Lebar bilah & $3 \mathrm{~cm}$ \\
\hline
\end{tabular}

Gambar tangki fermentor dan pengaduk yang dipabrikasi diperlihatkan pada gambar 2 .

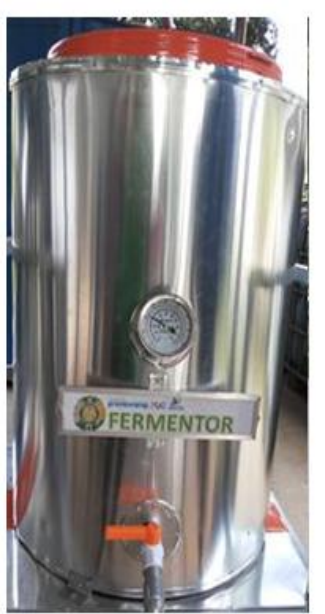

(a)

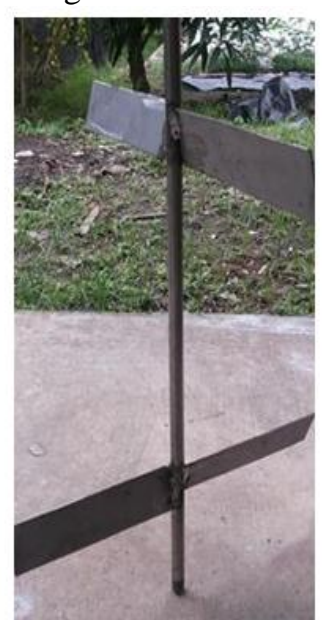

(b)
Gambar 2. (a) Tangki Fermentor (b) Pengaduk Paddle 
Tangki fermentor dipabrikasi menggunakan drum plastik dengan tinggi dan diameter masingmasing $86 \mathrm{~cm}$ dan $43 \mathrm{~cm}$. Tangki dilengkapi dengan pengaduk paddle berjumlah 2 buah yang dioperasikan secara manual dengan panjang bilah $30 \mathrm{~cm}$. Selain pengaduk, fermentor dilengkapi dengan termometer untuk mengetahui suhu fermentasi dan valve masuk dan keluar.

\section{Unit Distilasi}

Tangki distilasi berfungsi sebagai alat pemisah yang menggunakan prinsip perbedaan titik didih. Pada proses pembuatan bioetanol, tangki distilasi digunakan untuk memisahkan air dari etanol yang dihasilkan pada proses fermentasi, sehingga dihasilkan etanol dengan kadar yang lebih tinggi. Perancangan tangki distilasi sesuai dengan standar berikut [18]:

$$
\begin{aligned}
& \mathrm{H}_{\mathrm{h}}=\left\{\frac{D-d}{2}\right\} \times \tan \theta \\
& \mathrm{V}_{\mathrm{s}}=\pi / 4 \cdot \mathrm{D}_{\mathrm{t}}^{2} \cdot \mathrm{H}_{\mathrm{s}} \\
& \mathrm{D}_{\mathrm{t}}=\mathrm{D}_{\mathrm{h}} \\
& \mathrm{H}_{\mathrm{T}}=\mathrm{H}_{\mathrm{s}}+\mathrm{H}_{\mathrm{h}}
\end{aligned}
$$

\section{Keterangan:}

$$
\begin{array}{rlr}
\mathrm{V}_{\mathrm{s}} & =\text { Volume tangki } & (\mathrm{cm}) \\
\mathrm{D}_{\mathrm{t}}=\text { Diameter tangki } & (\mathrm{cm}) \\
\mathrm{D}_{\mathrm{h}}=\text { Diameter tutup } & (\mathrm{cm}) \\
\mathrm{H}_{\mathrm{s}}=\text { Tinggi tangki } & (\mathrm{cm}) \\
\mathrm{H}_{\mathrm{h}}=\text { Tinggi tutup } & (\mathrm{cm}) \\
\mathrm{H}_{\mathrm{T}}=\text { Tinggi total } & (\mathrm{cm})
\end{array}
$$

Sudut distilasi dirancang bentuk conical dengan $\theta=45^{\circ}$. Desain teknikal dari tangki distilasi ditampilkan pada gambar 3, sedangkan spesifikasi dari tangki distilasi ditampilkan pada tabel 2 .

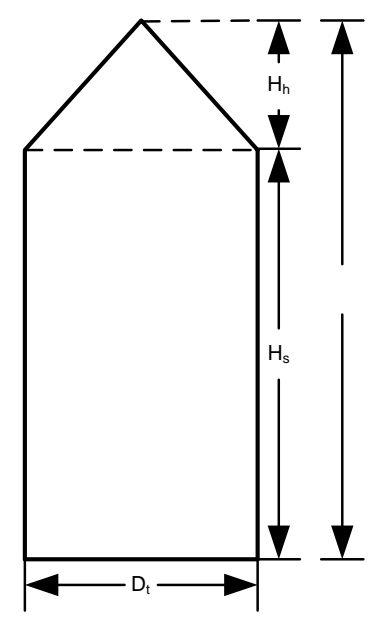

Gambar 3. Desain Teknikal Tangki Distilasi
Tabel 2. Spesifikasi Tangki Distilasi

\begin{tabular}{|ll|c|}
\hline \multicolumn{1}{|c|}{ Dimensi } & Besaran \\
\hline - & Tinggi tangki & $54 \mathrm{~cm}$ \\
- Diameter tangki & $48 \mathrm{~cm}$ \\
- Tinggi kerucut & $24 \mathrm{~cm}$ \\
\hline
\end{tabular}

Tangki distilasi dipabrikasi menggunakan bahan stainless steel dengan tangki berbentuk silinder dan tutup berbentuk kerucut. Jenis distilasi ini dinamakan pot distillation type. Tangki memiliki tinggi dan diameter masing-masing $54 \mathrm{~cm}$ dan $48 \mathrm{~cm}$, sedangkan tinggi kerucut tutup adalah $24 \mathrm{~cm}$. Tangki distilasi dilengkapi dengan jaket/insulasi berupa alumunium yang digunakan untuk mencegah penurunan suhu secara drastis apabila terjadi pemadaman listrik. Gambar 4 menampilkan hasil pabrikasi dari tangki distilasi.

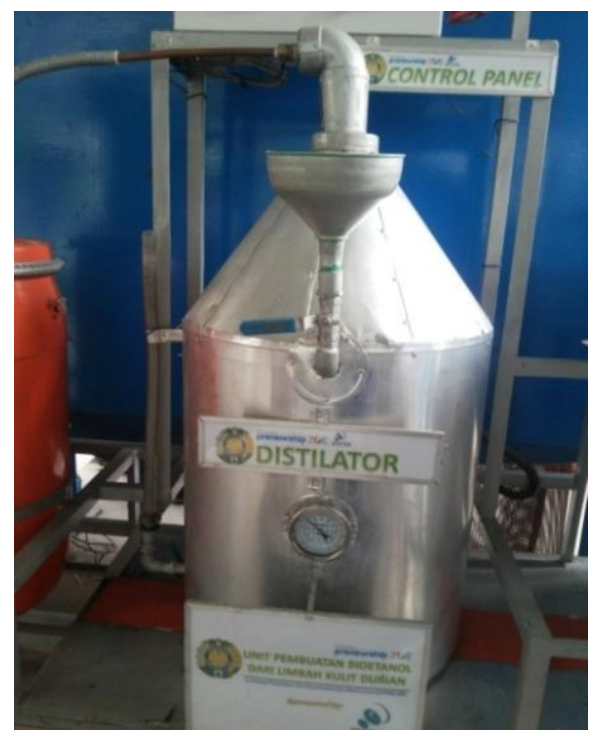

Gambar 4. Tangki Distilasi

Selain itu, tangki dilengkapi dengan heater dan tangki air pendingin. Heater berfungsi sebagai pemanas cairan yang terdapat di dalam tangki distilasi. Sedangkan tangki air pendingin berfungsi sebagai wadah penyimpanan air yang digunakan sebagai pendingin pada proses distilasi. Cairan distilasi yang dipanaskan akan menguapkan etanol yang terdapat pada cairan tersebut. Uap panas dari hasil distilasi akan disalurkan melalui pipa tembaga yang dihubungkan antara tangki distilasi dan tangki air pendingin. Uap panas tersebut akan dikondensasikan menggunakan air yang terdapat di dalam tangki air pendingin, sehingga etanol keluar dalam bentuk cair.

Tangki air pendingin terbuat dari drum plastik yang berbentuk tabung dengan volume 70 liter. Dilengkapi dengan koil tembaga dan valve keluarnya produk dan air buangan. Tabel 3 menampilkan spesifikasi tangki air pendingin dan 
gambar 5 menampilkan hasil pabrikasi tangki air pendingin.

Tabel 3. Spesifikasi Tangki Air Pendingin

\begin{tabular}{|l|c|}
\hline \multicolumn{1}{|c|}{ Dimensi } & Besaran \\
\hline Tangki & $66 \mathrm{~cm}$ \\
- Tinggi tangki & $37 \mathrm{~cm}$ \\
- Diameter tangki & \\
Koil Pendingin & 4 \\
- Jumlah lilitan & $30 \mathrm{~cm}$ \\
- Diameter koil & \\
\hline
\end{tabular}

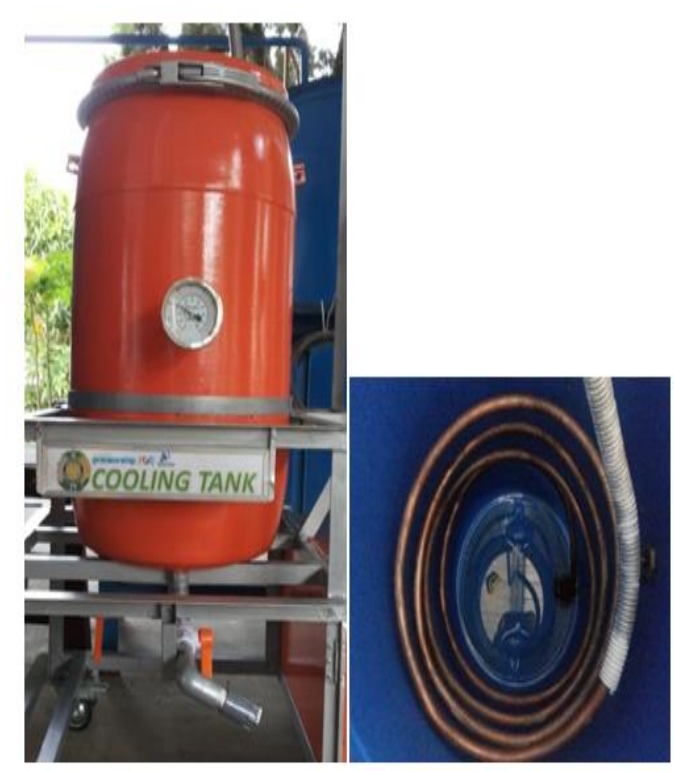

Gambar 5. Tangki Air Pendingin

\section{Waktu Siklus Proses Batch Pembuatan Bioetanol dengan Bahan Baku Kulit Durian}

Proses pembuatan bioetanol dapat dilakukan secara batch dan kontinu. Dalam penelitian ini, proses pembuatan bioetanol dengan bahan baku kulit durian dilakukan secara batch. Pembuatan bioetanol dengan proses batch dapat menghasilkan kadar etanol yang tinggi, tetapi membutuhkan waktu yang lama karena selain waktu produksi, waktu pengosongan dan pencucian peralatan juga diperhitungkan dalam siklus proses ini [7]. Tabel 4 menampilkan waktu siklus proses batch pembuatan bioetanol dengan bahan baku kulit durian.

Dalam sebuah proses batch tidak hanya waktu operasi atau waktu proses yang diperhitungkan, tetapi juga waktu pengisian, pengosongan dan pencucian tangki. Dari tabel 4 dapat disimpulkan bahwa waktu yang dibutuhkan untuk satu siklus proses pembuatan bioetanol dengan bahan baku kulit durian dengan kapasitas proses 100 liter adalah 8 hari 4 jam. Waktu tersebut meliputi waktu proses, pengisian, pengosongan dan pencucian tangki. Untuk proses fermentasi berlangsung selama 7 hari, pemilihan kondisi lama fermentasi ini berdasarkan penelitian hasil laboratorium yang telah dilakukan oleh Reviana (2014), dimana pada waktu fermentasi 7 hari diperoleh perolehan bioetanol optimum [14]. Sedangkan untuk proses fermentasi, waktu total yang dibutuhkan adalah 7 hari 7 jam. Waktu ini meliputi waktu proses, pengisian, pengosongan, penyaringan dan pencucian tangki.

Tabel 4. Waktu Siklus Proses Batch Pembuatan Bioetanol dengan Bahan Baku Kulit Durian

\begin{tabular}{|c|c|c|c|c|c|c|c|c|c|c|}
\hline \multirow{2}{*}{ No. } & \multirow{2}{*}{ Proses } & \multicolumn{9}{|c|}{ Waktu (Hari) } \\
\hline & & 1 & 2 & 3 & 4 & 5 & 6 & 7 & 8 & 9 \\
\hline 1. & Pengambilan bahan baku & & & & & & & & & \\
\hline 2. & \begin{tabular}{|l|} 
Pencucian kulit durian \\
\end{tabular} & & & & & & & & & \\
\hline 3. & Pemotongan kulit durian & & & & & & & & & \\
\hline 4. & Perebusan awal & & & & & & & & & \\
\hline 5. & Penghalusan kulit durian & & & & & & & & & \\
\hline 6. & Hidrolisis & & & & & & & & & \\
\hline \multirow[t]{6}{*}{7.} & Fermentasi & & & & & & & & & \\
\hline & - Pengisian tangki & & & & & & & & & \\
\hline & - Proses fermentasi & & & & & & & & & \\
\hline & - Pengosongan tangki & & & & & & & & & \\
\hline & - Penyaringan hasil fermentasi & & & & & & & & & \\
\hline & - Pencucian tangki & & & & & & & & & \\
\hline \multirow[t]{5}{*}{8.} & Distilasi & & & & & & & & & \\
\hline & - Pengisian tangki & & & & & & & & & \\
\hline & - Proses distilasi & & & & & & & & & \\
\hline & - Pengosongan tangki & & & & & & & & & \\
\hline & - Pencucian tangki & & & & & & & & & \\
\hline
\end{tabular}




\section{Pengujian Kelayakan Unit Pembuatan Bioetanol}

\section{Kalibrasi Unit Pembuatan Bioetanol dengan Bahan Baku Kulit Durian}

Kalibrasi/uji yang dilakukan meliputi uji kebocoran dan kalibrasi suhu. Setelah dilakukan tes kebocoran pada tangki fermentor, distilasi dan tangki air pendingin tidak terdapat kebocoran pada tangki tersebut. Sedangkan kalibrasi suhu dilakukan pada tangki distilasi untuk mengetahui perbedaan pembacaan suhu pada tangki distilasi dan pembacaan suhu pada control panel. Gambar 6 menampilkan hasil kalibrasi pembacaan suhu pada tangki distilasi.

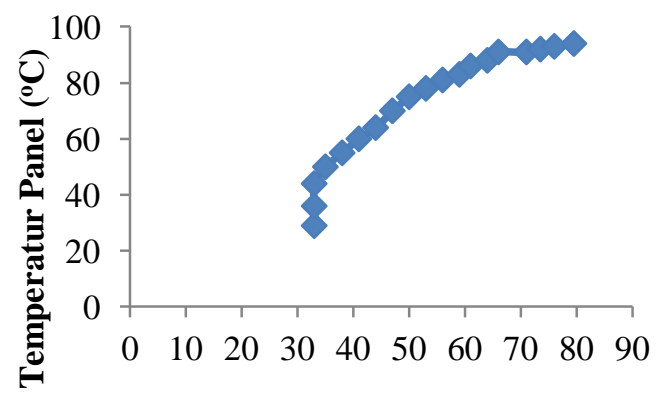

Temperatur Termometer $\left({ }^{\circ} \mathrm{C}\right)$

\section{Gambar 6. Kalibrasi Suhu pada Tangki Distilasi}

Hasil pembacaan suhu menunjukkan perbedaan pembacaan suhu dengan rentang 15$25^{\circ} \mathrm{C}$. Dari hasil kalibrasi ini diketahui lamanya waktu cairan di dalam tangki distilasi untuk mencapai suhu operasi $80^{\circ} \mathrm{C}$ yaitu selama 90 menit.

\section{Unjuk Kerja Unit Pembuatan Bioetanol dengan Bahan Baku Kulit Durian}

Unjuk kerja yang dilakukan meliputi tangki fermentor dan distilator. Penelitian pembuatan bioetanol dengan peralatan yang dibangun sesuai dengan kondisi proses pada skala laboratorium dengan bahan baku sebesar $25 \mathrm{~kg}$. Kulit durian dibersihkan dan dipotong-potong, setelah itu dilakukan perebusan awal sehingga kulit durian menjadi lunak. Setelah itu kulit durian dihaluskan dan dihidrolisis dengan air menggunakan panci bertekanan. Proses fermentasi yang dipilih merupakan kondisi optimum yang diperoleh dari penelitian skala laboratorium yaitu fermentasi selama 7 hari dan penambahan ragi 6\% dari berat bahan baku. Sedangkan distilasi dilakukan pada suhu $80^{\circ} \mathrm{C}$ selama 3 jam [14].

Cairan hasil fermentasi dan distilasi diukur kadar etanolnya dengan menggunakan GC. Diperoleh kadar etanol hasil fermentasi sebesar $8,98 \%$ dan kadar etanol hasil distilasi sebesar
$74,96 \%$. Cairan fermentasi yang dihasilkan sudah memenuhi standar dari kadar etanol hasil fermentasi secara teori yaitu 8-12\% [12]. Sedangkan etanol hasil distilasi masih diperlukan pemurnian lebih lanjut untuk mencapai standar mutu bioetanol yang ada.

\section{Kesimpulan}

Adapun kesimpulan yang dapat diambil dari penelitian ini adalah:

1. Pabrikasi unit pembuatan bioetanol dengan bahan baku kulit durian terdiri dari fermentor dan unit distilasi. Fermentor dibangun dengan tinggi dan diameter masing-masing sebesar 86 $\mathrm{cm}$ dan $43 \mathrm{~cm}$ dengan pengaduk paddle sebanyak 2 buah. Tangki ditilasi dibangun dengan tinggi dan diameter masing-masing sebesar $54 \mathrm{~cm}$ dan $48 \mathrm{~cm}$ dilengkapi dengan heater dan tangki air pendingin.

2. Waktu yang dibutuhkan untuk satu siklus proses fermentasi dan satu siklus proses pembuatan bioetanol, dimana kedu proses tersebut dilakukan secara batch, masing-masing adalah 7 hari 7 jam dan 8 hari 4 jam.

3. Dari uji kelayakan proses terhadap pembuatan bioetanol dari kulit durian dengan waktu fermentasi 7 hari, konsentrasi ragi 6\% dan temperatur distilasi $80^{\circ} \mathrm{C}$ diperoleh kadar bioetanol hasil fermentasi sebesar $8,98 \%$ dan kadar bioetanol hasil distilasi sebesar 74,96\%.

\section{Ucapan Terimakasih}

Penulis mengucapkan terimakasih kepada Kementrian Riset dan Teknologi Republik Indonesia yang telah mendanai penelitian ini melalui Technopreneurship Pemuda tahun 2012.

\section{Daftar Pustaka}

[1] Anonim, Design of Fermenter and Kinetics, 2010.

[2] Ardi, Wahyu Raditya, Pemurnian Etanol dari Tape Ubi Kayu (Manihot utilissima) (Kajian Suhu dan Lama Waktu Distilasi), Skripsi, Program Sarjana Fakultas Pertanian, Universitas Brawijaya, Malang, 2009.

[3] Donati, Gianni dan Paludetto, Renato, Scale Up of Chemical Reactors, Journal Catalysis Today. 34 : 483-485, 1997.

[4] Fitriana, Lila, Analisis Kadar Bioetanol Hasil Fermentasi Pati Sagu (Metroxylon sago) Asal Papua, Skripsi, Program Sarjana Fakultas Teknik, Universitas Negeri Papua, Jayapura, 2009.

[5] Geankoplis, C.J, Transport Process and Separation Process Principles, New Jersey: Prentice Hall, Fourth Edition, 2003.

[6] Hatta, Violet, Manfaat Kulit Durian Selezat Buahnya, Skripsi, Universitas Lampung, 2007. 
[7] Humaidah, Nurlaili, Produktivitas Etanol menggunakan Teknik Immobilisasi Sel KKaraginan dalam Bioreaktor Paked Bed, Skripsi, Fakultas Teknologi Industri, Institut Teknologi Sepuluh November, Surabaya, 2010.

[8] International Atomic Energy Agency, Guidebook on Design, Construction and Operation of Pilot Plants for Uranium Ore Processing, Vienna : International Atomic Energy Agency, 1990.

[9] Komarayati, Sri dan Gusmailina, Prospek Bioetanol sebagai Pengganti Minyak Tanah, Pusat Penelitian dan Pengembangan Hasil Hutan, Bogor, 2010.

[10] Kurniawan, Roni; Juhanda, S; Syamsudin, Rusyad dan Lukman Moh. Alief, Pengaruh Jenis dan Kecepatan Pengaduk pada Fermentasi Etanol Secara Sinambung dalam Bioreaktor Tangki Berpengaduk Sel Tertambat, Skripsi, Program Sarjana Fakultas Teknik, Institut Teknologi Nasional, Bandung, 2011.

[11] Mahatmandi, Widhi F dan Minarni, Optimalisasi Olahan Buah Durian sebagai Alternatif dalam Usaha Agrowisata Durian, Jurnal Penerapan Teknologi dan Pembelajaran, 8 (1) : 21-26, 2010.

[12] Peraturan Pemerintah, Peraturan Pemerintah No. 5 Tahun 2006 tentang Kebijakan Energi Nasional, Jakarta, 2006.

[13] Perdana, D.A, Kajian Tekno Ekonomi Perancangan Proes Produksi Bioetanol dari Limbah Tanaman Jagung, Skripsi, Program Sarjana Fakultas Pertanian, Institut Pertanian Bogor, Bogor, 2011.

[14] Revitasari, Reviana, Pengaruh Konsentrasi Ragi dan Lama Fermentasi terhadap Perolehan Bioetanol dari Kulit Durian, Skripsi, Fakultas Teknik, Universitas Sumatera Utara, 2014.

[15] Richana, Nur, Bioetanol (Bahan Baku, Teknologi, Produksi dan Pengendalian Mutu), Bandung: Penerbit Nuansa, 2011.

[16] Taherzadeh, Mohammad J dan Karimi, Keikhosro, "Pretreatment of Lignocellulosic Wastes to Improve Ethanol and Biogas Production: A Review", International Journal of Molecular Sciences, 9 : 1621-1651, 2009.

[17] Torija, Ma. Jesus; Rozes, Nicolas; Poblet, Montse; Guillamon, Jose Manuel dan Mas, Albert, "Effects of Fermentation Temperature on The Strain Population of Saccharomyces cerevisiae", International Journal of Food Microbiology, 80 : 47-53, 2002.

[18] Walas, Stanley M, Chemical Process Equipment: Selection and Design, Stoneham: Butterworth Publishers, 1988.
[19] Wooley, Robert; Ruth, Mark; Glassner, David; dan Sheehan, John, "Process Design and Costing of Bioethanol Technology: A Tool for Determining the Status and Direction of Research and Development", Biotechnology Progress. 15 :794-795, 1999. 